\title{
Molecular pathogenesis of craniopharyngioma: switching from a surgical approach to a biological one
}

\author{
Benedetta Ludovica Pettorini, M.D., Paolo Frassanito, M.D., \\ Massimo Caldarelli, M.D., Gianpiero Tamburrini, M.D., LuCa Massimi, M.D., \\ and Concezio Di Rocco, M.D.
}

Paediatric Neurosurgery Unit, Catholic University of Rome, Italy

\begin{abstract}
Craniopharyngioma has long been considered a benign tumor because of its pathological aspect. This primordial view of craniopharyngioma fit with the primitive treatment attempts based on blind resection of the tumor each time it recurred. The limits of this management strategy were proven early by the high morbidity related to the resection and recurrence risk despite radical lesion removal. Nowadays, craniopharyngioma must be considered a complex molecular disease, and a detailed explanation of the mechanisms underlying its aggressive biological and clinical behavior, despite some benign pathological features, would be the first step toward defining the best management of craniopharyngioma. Indeed, advances in the knowledge of the molecular mechanisms at the base of craniopharyngioma oncogenesis will lead to comprehension of the critical checkpoints involved in neoplastic transformation. The final research target will be the definition of new biological agents able to reverse the neoplastic process by acting on these critical checkpoints. This biological approach will lead to a refined therapy combining higher efficacy and safety with lower morbidity. In this paper the authors reveal state-of-the-art comprehension of the molecular biology of craniopharyngioma and the consequent therapeutic implications. (DOI: 10.3171/2010.1.FOCUSO9300)
\end{abstract}

\section{KEY WordS - craniopharyngioma - molecular biology • oncogenetic mechanism}

$\mathrm{C}$ RANIOPHARYNGIOMA accounts for $5-10 \%$ of childhood tumors. Two histological variants are known: adamantinomatous, typically occurring in the pediatric population, and the squamous papillary form, frequent in adults. These histological forms differ in pathological features, reflecting a distinct oncogenetic origin. Adamantinomatous craniopharyngiomas arise from a neoplastic transformation of the epithelial remnants of the craniopharyngeal duct, involuting during embryological development of the adenohypophysis. The squamous papillary variant arises from a metaplastic process involving the adenohypophyseal cells in the pars tuberalis, leading to the formation of squamous cell nests.

Although a purely surgical approach aimed at total resection has been advocated to cure craniopharyngiomas, this management strategy is often burdened by high morbidity because of the critical relationships of this tumor with neighboring vascular and nervous structures..$^{21,37}$ The identification of new therapies would help to comprehend the molecular mechanisms underlying the clinically aggressive behavior of these lesions. Although recent studies have been aimed at clarifying some aspect of neoplastic cell transformation, the molecular pathogenesis of craniopharyngiomas has not been systematically examined in literature. In this paper we attempted to

\footnotetext{
Abbreviations used in this paper: $\mathrm{IFN}=$ interferon; $\mathrm{MIF}=$ macrophage-inhibiting factor; $\mathrm{RAR}=$ retinoic acid receptor; VEGF = vascular endothelial growth factor.
}

critically review the recent literature on the oncogenetic mechanisms of craniopharyngiomas and their therapeutic implications.

\section{Molecular Pathogenesis}

The biological mechanisms at the base of the aggressive neoplastic nature of a lesion are as follows: 1) cellular proliferation depending on failure of the apoptotic pathway and activation of the antiapoptotic pathway or on sensitivity to growth factors, 2) cellular anaplasia, 3) local invasiveness, and 4) neoangiogenesis. These features are as strictly interrelated as the molecular mechanisms underlying them. In addition, every neoplastic lesion has another typical skill-namely, elusion of the immune system, which is essential to its existence. In craniopharyngiomas, the role of the immune response is even more complex, as discussed below.

Cellular Proliferation: Failure of the Apoptotic Pathway and Activation of the Antiapoptotic Pathway

Beta-Catenin and Wnt. Dysregulation of the Wnt signaling pathway could be a molecular mechanism involved in neoplastic cellular transformation. Under physiological conditions, binding of Wnt to a membrane receptor initiates an intracellular signaling cascade resulting in the inactivation of the cytoplasmic glycogen synthase kinase $3 \beta$ (GSK3beta) complex, including adenomatous polyposis coli, beta-catenin, Axin, and components of 


\section{B. L. Pettorini et al.}

the ubiquitin ligation machinery. Whereas this proteasomal complex is appointed to beta-catenin degradation, and consequently its inactivation, beta-catenin molecules can translocate into the nucleus, where they interact with members of the $\mathrm{T}$ cell factor family of transcription factors. ${ }^{8}$ Thus, intranuclear beta-catenin accumulation enhances the expression of target genes including c-myc and cyclin D1 ${ }^{14,45}$ and plays a fundamental role in proliferation as well as pattern formation, morphogenesis, and the evolution of polarity.

Recently, mutations of the glycogen synthase kinase $3 \beta$ binding domain of beta-catenin were detected in adamantinomatous craniopharyngioma as well as calcifying odontogenic cysts and pilomatricoma. . $^{13,19,38,39,47}$ These mutations could cause an aberrant and persistent activation of the pathway cited above, leading to an enhanced expression of Axin 2 and bone morphogenetic protein 4 in craniopharyngioma. ${ }^{15}$ The enhanced expression of Axin can be interpreted as a negative feedback of beta-catenin activity-namely an attempt of the cell to increase production of the component of proteasomal complex appointed to degradation of beta-catenin to decrease its cellular concentration and thus its nuclear activity.

Macrophage Migration Inhibiting Factors and Galectins. Macrophage-inhibiting factor is another molecule probably involved in the oncogenesis of craniopharyngioma. The MIF mRNA and protein are expressed in the normal human epidermis and nerve cells.,.$^{31,32,41}$ The influence of MIF has been described in various pathological conditions of the skin, ranging from inflammatory diseases to epidermal hyperplasia..$^{10,40,43}$ In this context MIF could act as a stimulator of tumor and vessel growth. ${ }^{28,30}$ In an indirect manner, the role of MIF in tumor cell growth was also demonstrated by evidence that anti-MIF antibodies effectively suppress tumor growth and tumor-associated angiogenesis. ${ }^{30}$

Under physiological conditions, MIF binds to Jab1 in the cell, which induces the phosphorylation of c-Jun and AP-1 and promotes the degradation of $\mathrm{p} 27 \mathrm{Kip} 1$; the result is a reduction in the growth-promoting effects of Jab1.,20 The MIF expression level seems to correlate with the risk of recurrence in craniopharyngioma, as it was significantly lower in rapidly recurring craniopharyngiomas than in the slowly recurring or nonrecurring lesions. ${ }^{23}$

Moreover, MIF expression in cholesteatomas correlates with an antiapoptotic endogenous lectin, namely, galectin-3. Indeed, mammalian galectins, which are betagalactoside-binding proteins, can also exert a notable influence on growth regulation through proapoptotic (for example, galectin-1) or antiapoptotic (for example, galectin-3) mechanisms. ${ }^{9,22,42}$

Analogous to MIF, galectin-3 levels of expression were significantly lower in rapidly recurrent craniopharyngiomas. ${ }^{23}$ In view of the antiapoptotic role of galectin-3, its low level of expression in recurring craniopharyngiomas seems to be related more to its role in phagocytosis. In this context the low levels of galectin-3 could correlate the oncogenesis of craniopharyngioma with defects in the normal biological elimination of embryonal tissue remnants. ${ }^{23}$

\section{Cellular Proliferation: Sensitivity to Growth Factors}

The environment in which craniopharyngiomas arise can play an important role, so that close contact with the pituitary gland and the hypothalamus may influence its growth.

Increased expression of mRNAs for estrogen and progesterone receptors has been observed in the proliferative epithelial component of craniopharyngiomas, ${ }^{46}$ and this message from the cytoplasm would be translated into biologically active receptor protein. ${ }^{16}$ Moreover, despite the increased expression of mRNA for estrogen receptors, coexpression of the estrogen receptor protein was finally detected on occasion, ${ }^{46}$ and the correlation with clinical outcome is not clear.

Estrogen and progesterone receptors could be markers of a high tissue differentiating potential, as their coexpression would be associated with a low risk of tumor regrowth. ${ }^{18}$

\section{Anaplasia: RAR}

The correlation of anaplasia with the risk of recurrence is well proved by the expression levels of RAR. Recurrent adamantinomatous craniopharyngiomas are characterized by low levels of RAR $\beta$ and high levels of RAR $\gamma .{ }^{25}$ The RARs belong to a major family of biological regulators that drive maturation in different types of epithelia (including the epidermis), as it is well known that the levels of expression of RAR isotypes differ markedly in relation to levels of maturation and/or differentiation of the epidermis. ${ }^{6,36}$

\section{Invasiveness: Cathepsins}

Recent studies have pointed out the role of cathepsins, a class of proteinases acting upstream of metalloproteinases in the proteolytic cascade, enabling tumor cells to invade adjacent normal tissue. Recurrent adamantinomatous craniopharyngiomas are characterized by low levels of cathepsin D and high levels of cathepsin K, and so revealing the same biphasic pattern of expression seen in RAR. ${ }^{25}$ On the contrary, although the expression of cathepsin $\mathrm{B}$ increases during the malignant progression of primary brain tumors and so is considered a significant prognostic factor, ${ }^{44}$ to date its level has not been shown to be related to the aggressiveness of craniopharyngioma. ${ }^{25}$

The mechanism acting downstream remains unclear. Cathepsin D secreted from human prostate carcinoma cells is responsible for the generation of angiostatin, a potent endogenous inhibitor of angiogenesis, and this suggests that it contributes to the prevention of tumor growth and the angiogenesis-dependent growth of metastases. ${ }^{48}$ The level of expression of cathepsin D is significantly higher in more differentiated craniopharyngiomas, showing concomitant high levels of RAR $\beta$ expression than in craniopharyngiomas with lower levels of RAR $\beta$ expression. ${ }^{25}$ The possibility thus remains that, as in the case of human prostate cancer cells, cathepsin D (high in the case of craniopharyngiomas with high levels of RAR $\beta$, and so more differentiated) facilitates the generation of angiostatin in craniopharyngiomas and thereby decreases postsurgical regrowth and/or recurrence. 
On the other hand, cathepsin $\mathrm{K}$ is a cysteine protease of the papain family, which can cleave bone proteins such as Type I collagen, osteopontin, and osteonectin. ${ }^{52}$ The knockout of cathepsin $\mathrm{K}$ in mice leads to retarded bone matrix degradation and osteopetrosis. ${ }^{52} \mathrm{~A}$ high level of cathepsin $\mathrm{K}$ was detected in recurrent craniopharyngiomas. ${ }^{23}$ Moreover, this finding seems to be related to cellular undifferentiation, represented by a pattern showing low levels of RAR $\beta$ and high levels of RAR $\gamma$.

\section{Neoangiogenesis: VEGF}

Neoangiogenesis is a limiting factor for tumor growth. Microvessel density, a measure of angiogenesis, has been proposed as a prognostic indicator correlating with an increased risk of recurrence. ${ }^{1,50}$ However, conflicting results on the relationships between microvessel density and the tissutal expression of vascularization stimulatory and inhibitory factors (VEGF and endostatin, respectively) $)^{1,5,50,51}$ could favor a modification able to enhance the neovascularization stimulus at the cytoplasmic level of postreceptor transduction of the signal or at the membrane level — namely, an increased concentration of a receptor such as VEGFR-2.,50 On the other hand, the degree of expression of VEGF seems to play an important role in tumor cyst formation. ${ }^{49}$

\section{Role of Immune System Response: Defensins}

After systematic consideration of the molecular mechanisms at the base of the growth of the solid component of craniopharyngiomas, we must specifically discuss cyst formation given that almost $90 \%$ of these tumors have a cystic component ${ }^{2}$ and that in $60 \%$ of cases the cystic portion is predominant. The cystic element is responsible for almost all the symptoms related to mass effect. Moreover, its presence is associated with a major risk of recurrence, and thus suggesting a proliferative mechanism in its genesis and growth.

Much recent research aims to characterize the cyst fluid to understand the mechanism of formation and to refine treatments able to reduce cyst volume and inhibit the formation of new cysts. Indeed, the formation mechanism of cystic fluid has always been debated: it could be the result of blood-brain barrier impairment, ${ }^{3}$ but surely an active secretory process takes part in its formation.

Recently, $\alpha$-defensins $1-3$ have been identified as relevant components of cyst fluid. ${ }^{34}$ The presence of these antimicrobial peptides would suggest a possible involvement of the innate immune response in the formation and maintenance of the craniopharyngioma-associated cyst. Indeed, human $\alpha$-defensins $1-3$ constitute $30-50 \%$ of the total protein content of neutrophil azurophil granules, ${ }^{11,12}$ with a well-known powerful antibacterial and antiviral activity. The $\alpha$-defensin expression is significantly increased in the saliva of patients with oral squamous cell carcinomas, ${ }^{26}$ in the fluid of jaw cysts, ${ }^{27}$ and in the plasma of patients with sepsis and meningitis. ${ }^{33}$ Moreover, the expression of these peptides decreases as a function of the effectiveness of intracystic IFN- $\alpha$ treatment and so correlates with clinical patient outcome. Authors of future studies should clarify whether the reduction in $\alpha$-defensins derives from a direct antitumoral effect of IFN- $\alpha$ on squamous epithelial cells of the craniopharyngioma cyst or from its immunomodulatory effects on the recruitment of cells of innate immune systems or whether both action mechanisms are implicated.

\section{Conclusions}

The term "craniopharyngioma" refers to "kaleidoscopic tumors, solid and cystic, which take origin from epithelial rests ascribable to an imperfect closure of the hypophysis or craniopharyngeal duct." 24 In this primordial view, the craniopharyngioma is a mass exerting compression and the distinction between the cystic and solid components is only grossly understood, but the term "kaleidoscopic" let us suppose that Cushing understood the complexity of this tumor.

Leading surgeons have devoted their efforts to clarifying the true nature of this tumor, namely, its malignant clinical behavior characterized by local invasiveness and a high rate of recurrence, which is in clear contradiction with its benign histological aspect. We hope that the view of this tumor as a complex molecular disease rather than a simple mass can be the first step in defining the best treatment.

Initial efforts have been focused on correlating the mitotic activity of craniopharyngioma with its clinical behavior, unfortunately producing conflicting results. ${ }^{29,35}$ These contradictions can be clarified by the current evolution from the "microscopic" view to the "molecular" view. In fact, at the molecular level the cellular proliferation results in multiple failures of the apoptotic pathway combined with persistent activation of the antiapoptotic pathway. The identification of the impaired stages of this circuitry could explain the difference in the incidence of recurrence despite similar mitotic activity.

Besides the cellular proliferation, other cellular physiological functions became abnormal as a result of the neoplastic transformation, and so affected the clinical behavior of craniopharyngioma. Therefore, the terms of the matter are even more complex.

Nowadays, advances in our knowledge of oncogenic mechanisms would lead us to identify critical checkpoints in tumor cell transformation, to drive the definition of specific therapeutic agents able to reverse the neoplastic process at these levels. In this context, this biological approach aims to defeat the tumor by "curing" only the abnormal neoplastic cell. An example of this new approach is the reactivation of the apoptotic pathway-that is, a physiological mechanism in the normal cell that is eluded by the neoplastic cell - as a result of treatment with intracystic IFN. ${ }^{17}$

The final target of this research will be the definition of a tailored therapy combining higher efficacy and safety with lower morbidity. This biological therapy would probably be based on multiple inhibitions that so far have been proved to be more efficient than a single-step inhibition in the treatment of different tumors. On the other hand, considering the immediate future, the definition of molecular markers of malignancy will allow us to stratify patients harboring a craniopharyngioma on the basis of 


\section{B. L. Pettorini et al.}

its biological aggressiveness, and consequently enabling the surgeon to modulate treatment intensity.

\section{Disclosure}

The authors report no conflict of interest concerning the materials or methods used in this study or the findings specified in this paper.

Author contributions to the study and manuscript preparation include the following. Conception and design: BL Pettorini. Acquisition of data: P Frassanito. Analysis and interpretation of data: BL Pettorini, P Frassanito. Drafting the article: BL Pettorini, P Frassanito. Critically revising the article: BL Pettorini. Reviewed final version of the manuscript and approved it for submission: BL Pettorini, C Di Rocco. Study supervision: BL Pettorini, M Caldarelli, G Tamburrini, L Massimi, C Di Rocco.

\section{References}

1. Agozzino L, Ferraraccio F, Accardo M, Esposito S, Agozzino M, Cuccurullo L: Morphological and ultrastructural findings of prognostic impact in craniopharyngiomas. Ultrastruct Pathol 30:143-150, 2006

2. Alén JF, Boto GR, Lagares A, de la Lama A, Gómez PA, Lobato RD: Intratumoural bleomycin as a treatment for recurrent cystic craniopharyngioma. Case report and review of the literature. Neurocirugia (Astur) 13:479-485, 2002

3. Arefyeva IA, Semenova JB, Zubairaev MS, Kondrasheva EA, Moshkin AV: Analysis of fluid in craniopharyngioma-related cysts in children: proteins, lactate and $\mathrm{pH}$. Acta Neurochir (Wien) 144:551-554, 2002

4. Bucala R: Signal transduction. A most interesting factor. Nature 408:146-147, 2000

5. Dallago CM, Oliveira MC, Barbosa-Coutinho LM, Ferreira NP: Angiogenesis in craniopharyngiomas: Microvascular density and tissue expression of the vascular endothelial growth factor (VEGF) and endostatin. Endocr Pathol 16:355-362, 2005

6. Elder JT, Aström A, Pettersson U, Tavakkol A, Krust A, Kastner $\mathrm{P}$, et al: Retinoic acid receptors and binding proteins in human skin. J Invest Dermatol 98 (6 Suppl):36S-41S, 1992

7. Elmaci L, Kurtkaya-Yapicier O, Ekinci G, Sav A, Pamir MN, Vidal S, et al: Metastatic papillary craniopharyngioma: case study and study of tumor angiogenesis. Neuro Oncol 4:123128,2002

8. Friedrich A, Kullmann F: [Familial adenomatous polyposis syndrome (FAP): pathogenesis and molecular mechanisms.] Med Klin (Munich) 98:776-782, 2003 (Ger)

9. Gabius HJ: Animal lectins. Eur J Biochem 243:543-576, 1997

10. Gabius HJ: Probing the cons and pros of lectin-induced immunomodulation: case studies for the mistletoe lectin and galectin-1. Biochimie 83:659-666, 2001

11. Ganz T, Lehrer RI: Defensins. Pharmacol Ther 66:191-205, 1995

12. Ganz T, Selsted ME, Lehrer RI: Defensins. Eur J Haematol 44:1-8, 1990

13. Hassanein AM, Glanz SM, Kessler HP, Eskin TA, Liu C: betaCatenin is expressed aberrantly in tumors expressing shadow cells. Pilomatricoma, craniopharyngioma, and calcifying odontogenic cyst. Am J Clin Pathol 120:732-736, 2003

14. He TC, Sparks AB, Rago C, Hermeking H, Zawel L, da Costa LT, et al: Identification of c-MYC as a target of the APC pathway. Science 281:1509-1512, 1998

15. Hölsken A, Kreutzer J, Hofmann BM, Hans V, Oppel F, Buchfelder M, et al: Target gene activation of the Wnt signaling pathway in nuclear beta-catenin accumulating cells of adamantinomatous craniopharyngiomas. Brain Pathol 19:357364,2009
16. Honegger J, Renner C, Fahlbusch R, Adams EF: Progesterone receptor gene expression in craniopharyngiomas and evidence for biological activity. Neurosurgery 41:1359-1364, 1997

17. Ierardi DF, Fernandes MJS, Silva IR, Thomazini-Gouveia J, Silva NS, Dastoli P, et al: Apoptosis in alpha interferon (IFNalpha) intratumoral chemotherapy for cystic craniopharyngiomas. Childs Nerv Syst 23:1041-1046, 2007

18. Izumoto S, Suzuki T, Kinoshita M, Hashiba T, Kagawa N, Wada K, et al: Immunohistochemical detection of female sex hormone receptors in craniopharyngiomas: correlation with clinical and histologic features. Surg Neurol 63:520-525, 2005

19. Kato K, Nakatani Y, Kanno H, Inayama Y, Ijiri R, Nagahara $\mathrm{N}$, et al: Possible linkage between specific histological structures and aberrant reactivation of the Wnt pathway in adamantinomatous craniopharyngioma. J Pathol 203:814-821, 2004

20. Kleemann R, Hausser A, Geiger G, Mischke R, Burger-Kentischer A, Flieger O, et al: Intracellular action of the cytokine MIF to modulate AP-1 activity and the cell cycle through Jab1. Nature 408:211-216, 2000

21. Komotar RJ, Roguski M, Bruce JN: Surgical management of craniopharyngiomas. J Neurooncol 92:283-296, 2009

22. Kopitz J, von Reitzenstein C, André S, Kaltner H, Uhl J, Ehemann V, et al: Negative regulation of neuroblastoma cell growth by carbohydrate-dependent surface binding of galectin-1 and functional divergence from galectin-3. J Biol Chem 276:35917-35923, 2001

23. Lefranc F, Chevalier C, Vinchon M, Dhellemmes P, Schüring MP, Kaltner H, et al: Characterization of the levels of expression of retinoic acid receptors, galectin-3, macrophage migration inhibiting factor, and p53 in 51 adamantinomatous craniopharyngiomas. J Neurosurg 98:145-153, 2003

24. Lindholm J, Nielsen EH: Craniopharyngioma: historical notes. Pituitary 12:352-359, 2009

25. Lubansu A, Ruchoux MM, Brotchi J, Salmon I, Kiss R, Lefranc F: Cathepsin B, D and K expression in adamantinomatous craniopharyngiomas relates to their levels of differentiation as determined by the patterns of retinoic acid receptor expression. Histopathology 43:563-572, 2003

26. Lundy FT, Orr DF, Gallagher JR, Maxwell P, Shaw C, Napier SS, et al: Identification and overexpression of human neutrophil $\alpha$-defensins (human neutrophil peptides 1,2 and 3) in squamous cell carcinomas of the human tongue. Oral Oncol 40:139-144, 2004

27. Mizukawa N, Sugiyama K, Ueno T, Mishima K, Takagi S, Sugahara T: Detection of human $\alpha$-defensin-1, an antimicrobial peptide, in the fluid of jaw cysts. Oral Surg Oral Med Oral Pathol 90:78-81, 2000

28. Nangia-Makker P, Baccarini S, Raz A: Carbohydrate-recognition and angiogenesis. Cancer Metastasis Rev 19:51-57, 2000

29. Nishi T, Kuratsu J, Takeshima H, Saito Y, Kochi M, Ushio Y: Prognostic significance of the MIB-1 labeling index for patient with craniopharyngioma. Int J Mol Med 3:157-161, 1999

30. Nishihira J: Macrophage migration inhibitory factor (MIF): its essential role in the immune system and cell growth. J Interferon Cytokine Res 20:751-762, 2000

31. Nishio Y, Minami A, Kato H, Kaneda K, Nishihira J: Identification of macrophage migration inhibitory factor (MIF) in rat peripheral nerves: its possible involvement in nerve regeneration. Biochim Biophys Acta 1453:74-82, 1999

32. Ogata A, Nishihira J, Suzuki T, Nagashima K, Tashiro K: Identification of macrophage migration inhibitory factor mRNA expression in neural cells of the rat brain by in situ hybridization. Neurosci Lett 246:173-177, 1998

33. Panyutich AV, Panyutich EA, Krapivin VA, Baturevich EA, Ganz T: Plasma defensin concentrations are elevated in patients with septicemia or bacterial meningitis. J Lab Clin Med 122:202-207, 1993 


\section{Molecular pathogenesis of craniopharyngioma}

34. Pettorini BL, Caldarelli M, Massimi L, Tamburrini G, Inzitari R, Fanali C, et al: Detection of alpha-defensin 1-3 in cystic craniopharyngioma fluid and their concentration decrease during interferon-alpha treatment. Childs Nerv Syst 24:654, 2008

35. Raghavan R, Dickey WT Jr, Margraf LR, White CL III, Coimbra C, Hynan LS, et al: Proliferative activity in craniopharyngiomas: clinicopathological correlations in adults and children. Surg Neurol 54:241-248, 2000

36. Redfern CPF, Todd C: Retinoic acid receptor expression in human skin keratinocytes and dermal fibroblasts in vitro. J Cell Sci 102:113-121, 1992

37. Sainte-Rose C, Puget S, Wray A, Zerah M, Grill J, Brauner R, et al: Craniopharyngioma: the pendulum of surgical management. Childs Nerv Syst 21:691-695, 2005

38. Sekine S, Sato S, Takata T, Fukuda Y, Ishida T, Kishino M, et al: Beta-catenin mutations are frequent in calcifying odontogenic cysts, but rare in ameloblastomas. Am J Pathol 163:1707-1712, 2003

39. Sekine S, Shibata T, Kokubu A, Morishita Y, Noguchi M, Nakanishi Y, et al: Craniopharyngiomas of adamantinomatous type harbor beta-catenin gene mutations. Am J Pathol 161:1997-2001, 2002

40. Shimizu T, Abe R, Ohkawara A, Mizue Y, Nishihira J: Macrophage migration inhibitory factor is an essential immunoregulatory cytokine in atopic dermatitis. Biochem Biophys Res Commun 240:173-178, 1997

41. Shimizu T, Ohkawara A, Nishihira J, Sakamoto W: Identification of macrophage migration inhibitory factor (MIF) in human skin and its immmunohistochemical localization. FEBS Lett 381:199-202, 1996

42. Sotomayor CE, Rabinovich GA: "Galectin-1 induces central and peripheral cell death: implications in T-cell physiopathology.” Dev Immunol 7:117-129, 2000

43. Steinhoff M, Meinhardt A, Steinhoff A, Gemsa D, Bucala $\mathrm{R}$, Bacher M: Evidence for a role of macrophage migration inhibitory factor in psoriatic skin disease. Br J Dermatol 141:1061-1066, 1999
44. Strojnik T, Kos J, Zidanik B, Golouh R, Lah T: Cathepsin B immunohistochemical staining in tumor and endothelial cells is a new prognostic factor for survival in patients with brain tumors. Clin Cancer Res 5:559-567, 1999

45. Tetsu O, McCormick F: Beta-catenin regulates expression of cyclin D1 in colon carcinoma cells. Nature 398:422-426, 1999

46. Thapar K, Stefaneanu L, Kovacs K, Scheithauer BW, Lloyd $\mathrm{RV}$, Muller PJ, et al: Estrogen receptor gene expression in craniopharyngiomas: an in situ hybridization study. Neurosurgery 35:1012-1017, 1994

47. Tsang WY: Only adamantinomatous but not papillary type of craniopharyngioma is associated with beta-catenin mutation. Adv Anat Pathol 11:223, 2004

48. Tsukuba T, Okamoto K, Yasuda Y, Morikawa W, Nakanishi $\mathrm{H}$, Yamamoto K: New functional aspects of cathepsin D and cathepsin E. Mol Cells 10:601-611, 2000

49. Vaquero J, Zurita M, de Oya S, Coca S, Morales C, Salas C: Expression of vascular permeability factor in craniopharyngioma. J Neurosurg 91:831-834, 1999

50. Vidal S, Kovacs K, Lloyd RV, Meyer FB, Scheithauer BW: Angiogenesis in patients with craniopharyngiomas: correlation with treatment and outcome. Cancer 94:738-745, 2002

51. Xu J, Zhang S, You C, Wang X, Zhou Q: Microvascular density and vascular endothelial growth factor have little correlation with prognosis of craniopharyngioma. Surg Neurol 66 (Suppl 1):S30-S34, 2006

52. Yamashita DS, Dodds RA: Cathepsin K and the design of inhibitors of cathepsin K. Curr Pharm Des 6:1-24, 2000

Manuscript submitted December 10, 2009.

Accepted January 5, 2010.

Address correspondence to: Benedetta Ludovica Pettorini, M.D., Paediatric Neurosurgery Unit, Catholic University Medical School, Largo Agostino Gemelli, 8, 00168 Rome, Italy. email: benedettaludovica@virgilio.it. 